\title{
An approach to evaluate mountain forest protection and management as a means for flood mitigation
}

\section{Janine Rüegg ( $\square$ janine.ruegg@unil.ch )}

Interdisciplinary Center for Mountain Research, University of Lausanne, Lausanne, Switzerland

Christine Moos ( $\square$ christine.moos@bfh.ch )

Alice Gentile

Gilles Luisier

Alexandre Elsig

Günther Prasicek

lago Otero

\section{Method Article}

Keywords: environmental law, ecosystem service, forest protection and management, flood protection and management, forest-hydrology interaction, forest-society interaction

Posted Date: October 29th, 2021

DOI: https://doi.org/10.21203/rs.3.rs-1022575/v1

License: @ (i) This work is licensed under a Creative Commons Attribution 4.0 International License. Read Full License 


\section{Abstract}

We are of the opinion that old environmental policies that are based on scientific knowledge at the time they are established need to be revisited in terms of the current knowledge and the effectiveness of these policies in protecting or promoting a particular ecosystem service. Here we use the first Swiss Federal Forest Law (1876) as a case example, which was established to protect mountain forests as a natural means of protection against natural hazards, particularly floods. We briefly summarize the current relevant scientific knowledge on i) reasons for reforestation in mountains and how the law may have contributed, ii) forest effects on hydrological regimes and their protection service against floods, and iii) other watershed changes affecting both reforestation and the forest-runoff interaction. We then present insights from a case study on the Upper Rhone catchments, which lead us to develop a methodological approach based on interdisciplinary collaboration among natural and social sciences to gain the needed data to answer the question of whether a forest protection law can serve as a means of flood protection. Specifically, we found that a means of data interpolation is key to answering this question given data are at different scales and resolutions, and suggest modeling methods to fill gaps. Such methods and collaborations are key for basing environmental laws and policies in current scientific knowledge and effectively manage ecosystems and their services.

\section{Introduction}

Environmental policies have the purpose to protect ecosystems in their structure and function to maintain the ecosystem services they provide. However, these policies are rarely revisited to investigate whether their assumptions agree with current scientific understanding, nor whether their implementation served to protect the targeted ecosystem services (McEldowney and McEldowney, 2011; Luo et al., 2015). The environmental policy of interest for this perspective is the first Swiss Federal Forest Law. It was established in 1876 following catastrophic flood events to preserve and restore the protective service of mountain forests against natural disasters, such as floods, by prohibiting clear-cutting and an excessive use of forests (Schuler, 2007). In the 19th century, wood was a critical resource for people in mountain areas and forests were often used as pastures within their agricultural production system (Stuber and Bürgi, 2001). The law was one of the factors contributing to a transition from net deforestation to net reforestation in the Swiss Alps and is believed to have substantially contributed to flood protection (Mather and Fairbairn, 2000; Reynard et al., 2001). However, whether reforestation was due to the law or other socio-economic changes and to what extent reforestation contributed to flood protection remains unclear.

The aim, assumption(s), and effects of the Forest Law need to be revisited to understand its role in reforestation and flood protection. The first question, based on the aim to conserve and expand forests, is whether, why and where the law triggered reforestation. The second question, based on the assumed protective role of forests, is whether such reforestation served to minimize flood risks. While forests were assumed to protect against floods in the late 19th century (e.g. Landolt, 1862; Culmann, 1865), in Switzerland and countries with similar laws such as France and Austria (Ford, 2004; Weiss, 2001), the actual effects of these laws on flood risk have not been systematically investigated. Yet, their investigation is critical to better understand the protection services of mountain forests and to adapt related environmental policies accordingly. 
Answering these questions is not the aim of this perspective but rather the approach required, namely an interdisciplinary collaboration combining insights from social and natural sciences. On the one hand, historical data on socioeconomic changes affecting forest cover simultaneously to the Forest Law are necessary to determine whether the law can be considered as the reason of reforestation (e.g. Loran et al., 2017). On the other hand, the scientific basis of forest-hydrology interactions must be considered to link any potential forest cover changes to floods (e.g. Eisenbies et al., 2007; Kirchner et al., 2020). Also, other factors that can alter the alleged influence of forests on floods need investigation (e.g. climatic and anthropogenic changes) (Calder, 2007).

In this perspective, we present a conceptual and methodological framework to enumerate the importance of legal forest protection on flood occurrence based on insights gained from a case study in the Upper Rhone catchment. Specifically, we i) elaborate on the law in relation to mountain forest cover changes and society in Switzerland; ii) synthesize the current understanding of forest effects on flood risk reduction; iii) explore additional factors potentially altering forest-hydrology interactions, and iv) suggest a methodological approach to evaluate the effects of forest protection on flood occurrence and present example results on the data for the sub-catchments of the Upper Rhone River (Switzerland). We conclude that studying the impacts of the Forest Law on flood protection can be evaluated and similar evaluation could enhance environmental policies regarding their provision of ecosystem services.

\section{A Synthesis Of Forest Effects On Catchment Hydrology And Flood Protection Services}

\subsection{Society and its past use of mountain forests in Switzerland}

The Swiss Federal Forest Law (1876) was instituted to protect mountain forests to increase their protection against natural hazards. It was the first environmental measure at the federal level in Switzerland. Its origin were the disastrous floods of 1868 and accompanying landslides that caused the deaths of 50 people and damages of 14 million Swiss francs (Pfister, 2002). The Swiss Forestry Society had already alerted the Swiss government in 1856 about the alleged negative effects of deforestation on flood control. These warnings were later supported by the expert reports of Elias Landolt and Carl Culmann (Landolt 1862, Culmann 1865). The general belief among experts and politicians at the time was that Alpine forests were diminishing due to cutting by the mountain populations (Blotnitzki, 1869). Thus, the crucial role of forests in the management of natural risks was added to the argument in favor of securing a sustainable yield. A commission of experts was appointed by the Federal Council to determine the causes of the floods of 1868 and the measures to be taken to better deal with future floods. It determined that heavy precipitation and snow melting due to the warm foehn wind were the main reason for the disaster. However, the commission's report also suggested that mountain forest cover may play a significant role in reducing the flood risk (Summermatter, 2005). Thus, the law was created to foster reforestation with the aim to increase the protection services of forests against natural hazards.

Before industrialization, increases in populations often led to a decrease in forest cover due to the need for wood in construction and heating, and of land for agriculture and pasture (Peltier, 2005) (Fig. 1; point 6). In Switzerland, the demand of wood increased after 1800 and inhabitants made heavy use of wood resources, 
resulting in a decrease in forested area (Schuler et al., 2007) which in turn affected on soil characteristics important for the water cycle (e.g., soil organic content, soil storage capacity; see section 2.2.). The mountain population was generally not very cooperative with following the forest law initially, as highlighted by cases of illegally cutting and selling wood (Journal et Feuille d'avis du Valais, 1914). Similarly, the interpretation of reforestation projects and forest cover change requires the consideration of additional factors, such as difficulties that arose due to a lack of seedlings (SCR 1883), conflicts with the local communities (SCR, 1881), a lack of forestry personnel (SCR, 1880), and the generally slow action taken by the cantonal and municipal authorities to implement the law-related subsidies of the Confederation (L'Ami du peuple, 1906). However, industrialization, the migration of inhabitants from rural mountain areas to cities, and the development of fossil fuels reduced the need for wood and forests were able to recover. These changes led to an increase in forest cover from around $20 \%$ in 1850 to $30 \%$ at the beginning of the 21 st century (Loran et al., 2016). As industrialization and the timing of the Forest Law coincided, methods are needed to disentangle how much of the realized reforestation can be attributed to the latter.

\subsection{Forest - catchment hydrology interactions}

The impact of forest cover on the hydrological regime has long been subject to scientific and political debate (Andréassian, 2004; Calder and Aylward, 2006). All agree that vegetation cover influences the effects of rainfall events (Fercher et al., 2018), whereby three regulating mechanisms can be distinguished (Fig. 1; points 2-4): i) increased water infiltration into soils (e.g. Gonzalez-Sosa et al. 2010; Neris et al., 2012); ii) increased water storage capacity in soils (e.g. Ferreira et al., 2004, Nijzink et al., 2016); and iii) reduced water flow velocity via increased evapotranspiration and flow path lengths through the catchment (Bradshaw et al., 2007; Moos et al., 2018). These mechanisms are often linked as a higher porosity of the soil with more meso- and macropores due to tree roots allows for higher/faster and deeper infiltration (Beven and Germann, 2013; Vereecken et al., 2016), while tree roots can also extract water from deeper soil horizons compared to other vegetation cover (Moore and Heilman, 2011). The interception of precipitation by leaves increases the flow path lengths of water thus decreasing the amount of water for infiltration at a point in time, and evaporation during dry periods removes up to $5-20 \mathrm{~mm}$ of precipitation that could otherwise enter the stream (Wahren et al., 2012). These effects, however, strongly depend on the season and the type and structure of vegetation (Anderson, 1976) (Fig. 1: 1). Furthermore, only few catchment scale studies on forest effects have been conducted (e.g. Jones and Grant, 1996; Storck et al., 1998; Guillemette et al., 2005), demonstrating that deforestation could reduce soil infiltration and shorten flow pathways, thus increasing runoff. In addition, trees stabilize slopes as they reinforce the soil with their root network and reduce soil pore water pressure (Bathurst et al., 2010; Schwarz et al., 2012). Consequently, forests can reduce the sediment availability in torrents and thus the risk of debris flows (Cannon et al., 2010; Seebald et al., 2019). Thus, forests are believed to affect hydrology, but as most studies on the forests' influence on floods have been conducted at local scales, their conclusions cannot be easily applied to other places without appropriate extrapolation methods.

Increasing catchment scales increases climate and terrain variability, potentially obscuring a causal link between forests and floods (Calder, 2007; van Dijk et al., 2009; Alewell and Bebi, 2011). For example, the forest effect on floods strongly depends on soil characteristics. Soils with low water storage capacity are only altered marginally by roots, thus forest effects on runoff can only be small (Badoux et al., 2006). It is often argued that the effects of forests are negligible at large scales and for extreme precipitation events (Calder, 
2007, van Dijk et al., 2009, Wahren et al., 2012). During extreme precipitation events infiltration rates are generally too low to cope with the amount of water arriving, or soil storage capacity may be exceeded. Thus, areas with few but intense precipitation events may profit less from forests than areas with longer and more moderate rainfall events (Viglione et al., 2016). The extrapolation methods need to include such cumulative forest effects moving downstream.

\subsection{Environmental and anthropogenic influences on the water cycle}

The hydrological regime of a mountain catchment depends on many factors, some of which potentially exert a stronger control on catchment hydrology than forests (Chang and Franczyk, 2008; Li et al., 2009). They include geologic setting and climate variation (Fig. 1: points 5 and 9). Structural geology affects the hydrograph as flow paths tend to develop along predefined structures (e.g., Howard, 1967; Kühni and Pfiffner, 2001), and runoff generation depends on altitude and orientation of the land-surface (Molnar et al., 2007, Roy et al., 2015). Climate varies in space, mainly as a function of latitude, elevation, topography, global circulation patterns, and time, with recent climate change being an important aspect for the evaluation of a centuries-old environmental law (Fig. 1; point 5). Since 1876, Swiss mean annual temperatures decreased by about $0.5^{\circ} \mathrm{C}$ in the late 19th century with a subsequent increase of about $2^{\circ} \mathrm{C}$ until today. Over the same period, average annual precipitation showed no significant trend in Switzerland (Brönnimann et al., 2014). Nevertheless, increasing temperatures led to an increase in runoff in glaciated catchments (Pellicciotti et al., 2010). Also, over $90 \%$ of Swiss weather stations show a positive trend in intensity and frequency of heavy precipitation events from 1901 to 2014 (Scherrer et al., 2016). These climate trends affect the water cycle but may also alter the structure and function of forests.

Factors beyond the natural environment can impact catchment hydrology, such as hydropower production, touristic infrastructure, and natural hazard mitigation (Verbunt et al., 2005) (Fig. 1; points 7 and 8). In Switzerland, the onset of modern hydropower generation took place in the late 19th century. Between 1945 and 1970, the country experienced a period of expansion with the opening of several storage plants in high alpine terrain (SFOE, 2020). As a result, downstream hydrology was altered drastically, with a reduction of flows except when releases from the storage plants occur. Verbunt et al. (2005) found a clear influence of water releases and storages by hydropower stations on the runoff of the Rhine basin. The analysis further revealed a significant, but localized, impact of urbanization and afforestation. Urbanization in the Swiss Alps, as related to mass tourism, started to develop in the middle of the 19th century (Reichen, 2013). This required the regulation of torrents to expand and protect alpine settlements and infrastructure (Fig. 1; points 7 and 8 ). First attempts of river regulation in Switzerland date back to the 18th century with large-scale interventions commencing in the 19th and 20th century (Woolsey et al., 2005). In the Swiss Alps, $61 \%$ of the rivers are in a (near-)natural ecomorphological condition, as are $82 \%$ of the rivers above $2000 \mathrm{~m}$ (Zeh Weissmann et al., 2009). However, obstructions such as weirs and dams are widespread in Switzerland and can influence the hydrograph and sediment transport capacity. All these factors, individually or jointly, can have far reaching influences on a (sub-)catchment's hydrology, the forest cover and structure, their interaction, and thus flood risk. An evaluation approach thus needs to allow such factors to be incorporated. 


\section{Evaluating The Efficacy Of The Swiss Federal Forest Law In Flood Protection}

\subsection{Proposed methodological approach}

Based on an interdisciplinary case study in the Upper Rhone catchment in Switzerland, we elaborated a potential methodological approach allowing for the evaluation of the Swiss Federal Forest Law as a means for flood protection (Fig. 2). We included a variety of data from different sources, using methods from historical and natural sciences. We focused on hydrological (flow, water level) and meteorological (precipitation, humidity, wind, temperature) data from sensor stations maintained by municipal, canton or federal agencies, topographical data (e.g., digital elevation model) and land cover data using historical maps, orthophotos, and photography. For historical data we accessed archival newspapers and the Valais State archives (Table 1). These data provided the database (Fig. 2; lilac), which then serves as input for modelling (Fig. 2; tangerine). Historical and current forest cover and flow data rarely have the same temporal and spatial resolution, requiring methods for inter- and extrapolation adapted to the data types. By processing collected data directly or indirectly (Fig. 2; tangerine) intermediate results can be created, namely the conditions of forest and hydrographs at different points in space and time, in relation to climate conditions (Fig. 2; green). However, run-off models generally incorporate forest cover and structure insufficiently or at coarse scales (e.g., Adams et al., 2010; Moos et al., 2018; Speich et al.,

2020). Therefore, the development of an adapted forest runoff model (Fig. 3; blue), depending on the forest state and the climate and catchment conditions, is necessary to realistically reconstruct hydrographs (e.g., Scheidl et al. 2020). Such a hydrological model will need to appropriately represent forest effects, which is rarely done (but see Zemokost, which includes vegetation cover type, Fercher et al., 2018), by, for example, considering canopy cover, roots, and evapotranspiration (Fig. 1). Additionally, the models will need to address changes to the hydrological cycle via water extractions to separate their effects from that of the forest where possible. An appropriate model could then indicate whether forest effects are also relevant during extreme climate events, which are generally those leading to most damages on infrastructure and society. The combined approach should be able to answer the initially proposed question of whether an environmental law protecting forests can also reduce flood risk.

\subsection{Evaluating the availability of input data}

In order to assess whether the required input data for the proposed approach are available, we divided the Upper Rhone catchment into 46 regions based on sub-catchments (Fig. 3A,B) . We then focused in depth data collection on five regions: Vouvry, Val d'Illiez, Lötschental, Val de Bagnes, and Zermattertal (Fig 3B). Except for two regions, we found at least some information (e.g., forest data or weather, hydrometric, or hydropower stations), though at times limited in scope (space and/or time). Only 19 sub-catchments had hydrometric stations that provided some type of flow rate (e.g., stage, discharge, velocity). Even the five most intensely investigated regions differed in the spatial and temporal resolution of the data (Table 2, Fig 3B). Some have detailed flow rates for decades (e.g., Val de Bagnes), others are more limited (e.g., Vouvry), while documentation on forest cover is available over different periods and resolutions (e.g. Fig 3C). In general, data from these five sub-catchments are valuable and informative, but unfortunately present challenges. 
Table 1. Details of the historical data record research. 


\begin{tabular}{|lll|}
\hline Source & Keywords / collections & Document types \\
& & \\
$\begin{array}{l}\text { Swiss newspaper e } \\
\text { collection: }\end{array}$ & $\begin{array}{l}\text { Reforestation } \\
\text { (reboisement) }\end{array}$ & News articles \\
$\begin{array}{l}\text { www.e- } \\
\text { newspaperarchives.ch }\end{array}$ & $\begin{array}{l}\text { Reforestation project } \\
\text { (projet de reboisement) }\end{array}$ & \\
& $\begin{array}{l}\text { Deforestation } \\
\text { (déboisement) } \\
\end{array}$ & - Flood (inundation)
\end{tabular}

Médiathèque Valais:

\section{Digitized archive photographs}

(Collection audiovisuelle du Valais)
- Vouvry

- Val d'Illiez

- Val de Bagnes

- Lötschental

- Zermattertal

\section{Valais State Archives}

- $\quad \mathrm{CH}$ AEV, DI Département de l'Intérieur

- C CH AEV, 3 DTP Routes, Rhône, mines, forêts, 1608-1957

- . CH AEV, 6300 Service des cours d'eau

- CH AEV, 6900 Service des forêts et du paysage

- CH AEV, 6931-6939 Arrondissements forestiers
- Maps of the municipal forests (from about 1880)

- Forest management plans (location, division and ownership of forests) (from 1882)

- Technical reports of reforestation projects (description, area to be reforested, map) (from about 1930)

- Special description of forests (forest division, wooded/non-wooded/barren hectares, exposure, soil type, species + proportion, age, observations) (from 1882)

- Various forestry statistics (list of all reforestation projects, number of trees planted overall, forest area of communes) (from 1880)

- Watercourse correction plans (longitudinal profile, cross profile)

- Description of torrent correction work

- Photographs

\section{Swiss Federal}

\section{Archives}

- AFS EDI

E3270A\#1.10.3

Aufforstungen und

Verbauungen (1872-1985)

- . AFS EDI E3210A*

Bundesamt für

Wasserwirtschaft:
- Reforestation technical reports

- Description of the torrents

- Hydroelectric projects 
Many reforestation projects are reported; between 1870 and 1980, there were 435 reforestation projects in Valais (Archival Documents, 2004). Not all projects, however, state the reason for, and success of, the reforestation. Aerial and terrestrial photography provide a data record of the forest cover change, but methods need to be developed to fill in spatial and temporal data gaps (i.e., 3.1.).

Challenges in determining flood occurrence and risk are many-fold. Flow rates, and thus the ability to determine flood frequency, are only measured continuously/daily for a maximum of 46 years, starting a hundred years after the inception of the Forest Law. Newspaper articles provide some information on prior flood occurrence (data not presented), but the severity and definition of flood is unclear. A confounding factor evident in our five regions was that of hydropower installations. They can completely change the hydrology of a catchment, likely altering the influence the forest may exert on the hydrological dynamics.

The results of our Upper Rhone catchment case study indicate that the input data needed to determine whether the Forest Law affected flood regimes (Fig. 2) are available, but their collection and interpretation require an interdisciplinary approach enabling a holistic study of the forest's effects on runoff along changing social-ecological conditions. The information we presented indicates that data are not distributed evenly in space or time, but that catchments exist where enough data are available to develop models to fill data gaps. As our case study only covered a small portion of the Swiss mountain region with a specific climate, these models need to allow for the variation in driving climate variables and their interactions with forest ecosystems and hydrology. However, we posit that enough data can be found throughout Switzerland and potentially other countries with similar laws to evaluate the effects of mountain forest protection on flood risk using our methodological approach (Fig. 2).

\subsection{Interdisciplinary collaboration}

Our experiences made it clear that the team needed to undertake such research should include at least a forest scientist/engineer, a hydrologist, an environmental historian, and a geographer. We think that the question raised at the beginning of the manuscript can be answered, if $i)$ the research team is interdisciplinary and interactions between disciplines are properly planned and monitored, ii) the team is given enough time and resources for data collection on a large geographical scope and for frequent interactions, and iii) the data collected and modeled will be combined with statistical analyses of empirical runoff data in relation to forest state to answer the research question in a robust way. Only a joint methodological and interdisciplinary approach can draw a clear conclusion on the effectiveness of the first Swiss Federal Forest Law and its role in flood protection.

Table 2. Summary of data availability of the five sub-catchments selected for intense study. Data are presented for flow rate (top) and forest cover (bottom). Range indicates the first (and last if applicable) year of data collection, with data of higher resolution presented first. Resolution presents the temporal scale at which flow rates were collected/summarized, and the metric indicates the form of the data. If two data series 
are available, the one with the higher resolution is presented first, which is then reflected also in the resolution and metric in case they were different.

\begin{tabular}{|c|c|c|c|c|c|c|}
\hline & & Vouvry & Val d'Illiez & Lötschental & $\begin{array}{l}\text { Val de } \\
\text { Bagnes }\end{array}$ & Zermattertal \\
\hline \multirow[t]{3}{*}{$\begin{array}{l}\text { Flow } \\
\text { rate }\end{array}$} & Range & $\begin{array}{l}2010 \text { to } \\
2015, \\
\text { but not } \\
\text { continious }\end{array}$ & since 2001 & since 1956 & $\begin{array}{l}\text { since 1974; } \\
1911\end{array}$ & $\begin{array}{l}1974 \text { to } \\
1996 ; 1903 \\
\text { to } 1912 \text { and } \\
1922 \text { to } \\
2015\end{array}$ \\
\hline & Resolution & daily & $\begin{array}{l}\text { every } 5 \\
\text { minutes }\end{array}$ & unclear $^{\mathrm{a}}$ & $\begin{array}{l}\text { daily; } \\
\text { monthly }\end{array}$ & $\begin{array}{l}\text { daily; } \\
\text { monthly }\end{array}$ \\
\hline & Metric & mean & instantaneous & unclear $^{b}$ & $\max$ & $\max$ \\
\hline \multirow[t]{4}{*}{$\begin{array}{l}\text { Forest } \\
\text { cover }\end{array}$} & $\begin{array}{l}\text { Photography } \\
\text { (Swisstopo, } \\
\text { audiovisual) }\end{array}$ & $\begin{array}{l}\text { aerial from } \\
\text { 1942; } \\
\text { landscape } \\
\text { from } 1890\end{array}$ & $\begin{array}{l}\text { aerial from } \\
\text { 1945; } \\
\text { landscape } \\
\text { from } 1865\end{array}$ & $\begin{array}{l}\text { aerial from } \\
\text { 1950; } \\
\text { landscape } \\
\text { from } 1900\end{array}$ & $\begin{array}{l}\text { aerial from } \\
\text { 1935; } \\
\text { landscape } \\
\text { from } 1892\end{array}$ & $\begin{array}{l}\text { aerial from } \\
1929 ; \\
\text { landscape } \\
\text { from } 1865\end{array}$ \\
\hline & Reforestation & $\begin{array}{l}8 \text { projects } \\
\text { first in } 1872\end{array}$ & $\begin{array}{l}12 \text { projects } \\
\text { first in } 1881\end{array}$ & $\begin{array}{l}18 \text { projects } \\
\text { first in } 1874\end{array}$ & $\begin{array}{l}6 \text { projects } \\
\text { first in } \\
1881\end{array}$ & $\begin{array}{l}4 \text { projects } \\
\text { first in } 1920\end{array}$ \\
\hline & $\begin{array}{l}\text { Archival } \\
\text { documents }\end{array}$ & $\begin{array}{l}27 \\
\text { texts/maps }\end{array}$ & $\begin{array}{l}29 \\
\text { texts/maps }\end{array}$ & 0 texts/maps & $\begin{array}{l}9 \\
\text { texts/maps }\end{array}$ & $\begin{array}{l}3 \\
\text { texts/maps }\end{array}$ \\
\hline & & $\begin{array}{l}2 \\
\text { photographs }\end{array}$ & $\begin{array}{l}4 \\
\text { photographs }\end{array}$ & $\begin{array}{l}0 \\
\text { photograph }\end{array}$ & $\begin{array}{l}1 \\
\text { photograph }\end{array}$ & $\begin{array}{l}0 \\
\text { photograph }\end{array}$ \\
\hline
\end{tabular}

${ }^{a}$ https://www.hydrodaten.admin.ch/fr/2269.html b Inquery open with the FOEN

\section{Conclusions And Outlook}

In this perspective we posit that science can play a crucial role in monitoring and quantifying the potential effects of environmental policies on the provision of ecosystem services. We offer important insights on the complex interactions of an environmental law's (assumed) scientific basis, its impacts on the environment, as well as the evaluation of its efficacy. In Alpine countries, the establishment of forest laws preventing deforestation in mountain areas has generally been regarded as a great success, although the scientific debate on their benefits remains. Thus, it is essential to enhance the current scientific basis of the Forest Law's effects on the provisioning of flood protection services, determine the efficacy of the law in affecting reforestation and use models to link forest, climate, and hydrology. Findings based on our proposed interdisciplinary approach will not only be relevant for Alpine countries, but other mountain regions, such as 
the Himalaya or Taiwan, where similar conflicts exist due to the strong dependence of upland communities on wooden resources (e.g. Cheng et al., 2002; Chen et al., 2004; Wasson et al., 2008).

Our study emphasizes the necessity of a true interdisciplinary approach, combining a variety of methods from natural and social sciences. This allows for consideration and combination of a variety of data sources as well as different temporal and spatial scales relevant for assessing the impacts of forest changes on flood risk. The interdisciplinary framework we developed and presented here can further serve as an example for other ecosystem services, where similar questions on the effects of environmental practices and policies arise. Only a regular scientific questioning of the assumptions and purposes of environmental laws and policies can guarantee an effective management of ecosystem services.

\section{Declarations}

\section{Author contributions}

All authors contributed to the ideas in this manuscript through discussion during a feasibility study. JR, CM, $A E$, and $G P$ obtained the funding for $A G$ and $G L$ to conduct the on-the-ground data collection for the feasibility study. All authors wrote sections of the manuscript, led by JR and CM who then joined and unified them. All authors provided multiple rounds of extensive comments on the entire manuscript.

\section{Acknowledgements}

We thank the UNIL's CIRM seed funding program for allowing us to explore the feasibility of answering the postulated research questions.

\section{Competing interests}

The authors declare no competing interests.

\section{References}

Adams, M., G. Markart, and U. Stary. 2010. A comparison of hydrological models for forest management and climate change. How can existing models capture and reproduce hydrological effects of forests? Department of Natural Hazards and Alpine Timberline, Federal Research and Training Centre for Forests, Natural Hazards and Landscapes (BFW), Innsbruck.

Alewell, C., and P. Bebi. 2011. Forest development in the European Alps and potential consequences on hydrological regime. In: Forest management and the water cycle: An ecosystem-based approach.

Anderson, T.W. 1976. Evapotranspiration losses from flood-plain areas in central Arizona. US Geological Survey No. 76-864.

L'Ami du people. 1906. №63. Accessed via https://www.e-newspaperarchives.ch 
Andréassian, V. 2004. Waters and forests: from historical controversy to scientific debate. Journal of Hydrology 291:1-27.

Archival Documents. 2004. Identified via https://scopequery.vs.ch/suchinfo.aspx, CH AEV, 6900 - 200484 , Box 2015, accessed physically in the archives.

Badoux, A., M. Jeisy, H. Kienholz, P. Lüscher, R. Weingartner, J. Witzig, and C. Hegg. 2006. Influence of storm damage on the runoff generation in two sub-catchments of the Sperbelgraben, Swiss Emmental. European Journal of Forest Research 125:27-41.

Bathurst, J.C., C.I. Bovolo, and F. Cisneros. 2010. Modelling the effect of forest cover on shallow landslides at the river basin scale. Ecological Engineering 36:317-327.

Beven, K.J., and P.F. Germann. 2013. Macropores and water flow in soils revisited. Water Resources Research 49:3071-3092.

Blotnitzki, L. 1869. Rapport au Département de l'Intérieur de la Confédération suisse sur les inondations de I'an 1868 en Valais. Médiathèque Valais de Sion.

Bradshaw, C.J.A., N.S. Sodhi, K.S.-H. Peh, and B.W. Brook. 2007. Global evidence that deforestation amplifies flood risk and severity in the developing word. Global Change Biology 13 : 2379-2395.

Brönnimann, S., C. Appenzeller, M. Croci-Maspoli, J. Fuhrer, M. Grosjean, R. Hohmann, K. Ingold, R. Knutti, M.A. Liniger, C.C. Raible, R. Röthlisberger, C. Schär, S.C. Scherrer, K. Strassmann, and P. Thalmann. 2014. Climate change in Switzerland: a review of physical, institutional, and political aspects. WIRE's Climate Change 5:461481.

Calder, I.R., and B. Aylward. 2006. Forests and floods. Moving to an evidence-based approach to watershed and integrated flood management. Water International 31:87-99.

Calder, I.R. 2007. Forests and water - ensuring forest benefits outweigh water costs. Forest Ecology and Management 25:110-120.

Cannon, S.H., J.E. Gartner, M.G. Rupert, J.A. Michael, A.H. Rea, and C. Parrett. 2010. Predicting the probability and volume of post-wildfire debris flows in the intermountain western United States. Geological Society of America Bulletin 122:127-144.

Chang, H., and J. Franczyk. 2008. Climate change, land-use change, and foods: toward an integrated assessment. Geography Compass 2:1549-1579.

Chen, C.T.A., J.T. Liu, and B.J. Tsuang. 2004. Island-based catchment-The Taiwan example. Regional Environmental Change $4: 39-48$.

Cheng, J.D., L.L. Lin, and H.S. Lu. 2002. Influences of forests on water flows from headwater watersheds in Taiwan. Forest Ecology and Management $165: 11-28$. 
Culmann, C. 1865. Rapport au Conseil fédéral sur les torrents des Alpes suisses inspectés en 1858, 1859, 1860 et 1863. L. Corbaz.

van Dijk, A., M. van Noordwijk, I. Calder, S. Bruijnzel, J. Schellekens, and N.A. Chappell. 2009. Forest-flood relation still tenuous - comment on 'global evidence that deforestation amplifies flood risk and severity in the developing world' by C.J.A. Bradshaw, N.S. Sodi, K.S.-H. Peh and B.W. Brook. Global Change Biology 15:110115.

Eisenbies, M.H., W.M. Aust, J.A. Burger, and M.B. Adams. 2007. Forest operations, extreme flooding events, and considerations for hydrologic modeling in the Appalachians-a review. Forest Ecology and Management 242:77-98.

Fercher, M., M.H. Mueller, and A. Alaoui. 2018. Modelling the impact of land use changes on peak discharge in the Urseren Valley, Central Swiss Alps. Catena 163:321-331.

Ferreira, S.J.F., F.J. Luizão, S.M. Ross, Y. Biot, and W.M.P. Mello-Ivo. 2004. Soil water storage in an upland forest after selective logging in Central Amazonia. Revista Brasileira de Ciência do Solo 28:59-66.

Ford, C. 2004. Nature, culture and conservation in France and her colonies 1840-1940. Past \& Present 183:173-198.

Gonzalez-Sosa, E., I. Braud, J. Dehotin, L. Lassabatère, R. Angulo-Jaramillo, M. Lagouy, F. Branger, C. Jacqueminet, S. Kermadi, and K. Michel. 2010. Impact of land use on the hydraulic properties of the topsoil in a small French catchment. Hydrological Processes 24:2382-2399.

Guillemette, F., A.P. Plamondon, M. Prévost, and D. Lévesque. 2005. Rainfall generated stormflow response to clearcutting a boreal forest: peak flow comparison with 50 world-wide basin studies. Journal of Hydrology 302:137-153.

Howard, A.D. 1967. Drainage analysis in geologic interpretation: a summation. AAPG Bulletin 51:2246-2259. Jones, J.A., and G.E. Grant. 1996. Peak flow responses to clear-cutting and roads in small and large basins, western cascades, Oregon. Water Resources Research 32:959-974.

Journal et Feuille d'avis du Valais. 1906. ํ103. Accessed via https://www.e-newspaperarchives.ch Kirchner, J.W., W.R. Berghuijs, T.S. Allen, S.T. Allen, M. Hrachowitz, R. Hut, and D.M. Rizzo. 2020. Streamflow response to forest management. Nature 578:E12-E15.

Kühni, A., and O.A. Pfiffner. 2001. Drainage patterns and tectonic forcing: a model study for the Swiss Alps. Basin Research 13:169-197.

Landolt, E. 1862. Rapport au Conseil fédéral sur les forêts des hautes montagnes de la Suisse inspectées dans les années 1858, 1859 et 1860. L. Corbaz. 
Li, Z., W. Liu, X. Zhang, and F. Zheng. 2009. Impacts of land use change and climate variability on hydrology in an agricultural catchment on the Loess Plateau of China. Journal of Hydrology 377:35-42.

Loran, C., C. Ginzler, and M. Bürgi 2016. Evaluating forest transition based on a multi-scale approach: forest area dynamics in Switzerland 1850-2000. Regional Environmental Change 16:1807-1818.

Loran, C., C. Munteanu, P.H. Verburg, D.R. Schmatz, M. Bürgi, and N.E. Zimmermann. 2017. Long-term change in drivers of forest cover expansion: an analysis for Switzerland (1850-2000). Regional Environmental Change 17:2223-2235.

Luo, P., B. He, K. Takara, Y.E. Xiong, D. Nover, W. Duan, and K. Fukushi. 2015. Historical assessment of Chinese and Japanese flood management policies and implications for managing future floods. Environmental Science \& Policy 48:265-277

Mather, A., and J. Fairbairn. 2000. From floods to reforestation: the forest transition in Switzerland. Environment and History 6:399-421.

McCulloch, J.S., and M. Robinson. 1993. History of forest hydrology. Journal of Hydrology 150:189-216.

McEldowney, J., and S. McEldowney. 2011. Science and environmental law: collaboration across the double helix. Environmental Law Review 13:169-198.

Molnar, P., R.S. Anderson, and S.P. Anderson. 2007. Tectonics, fracturing of rock, and erosion. Journal of Geophysical Research: Earth Surface 112(F3).

Moos, C., P. Bebi, M. Schwarz, M. Stoffel, K. Sudmeier-Rieux, and L. Dorren. 2018. Ecosystem-based disaster risk reduction in mountains. Earth-Science Reviews 177:497-513.

Moore, G.W., and J.L Heilman. 2011. Proposed principles governing how vegetation changes affect transpiration. Ecohydrology 4:351-358.

Neris, J., C. Jiménez, J. Fuentes, G. Morillas, and M. Tejedor. 2012. Vegetation and land-use effects on soil properties and water infiltration of Andisols in Tenerife (Canary Islands, Spain). Catena 98:55-62.

Nijzink, R., C. Hutton, I. Pechlivanidis, R. Capell, B. Arheimer, J. Freer, D. Han, T. Wagener, K. McGuire, H. Savenije, and M. Hrachowitz. 2016. The evolution of root-zone moisture capacities after deforestation: a step towards hydrological predictions under change? Hydrology and Earth System Sciences 20:4775-4799.

Pellicciotti, F., A. Bauder, and M. Parola. 2010. Effect of glaciers on streamflow trends in the Swiss Alps. Water Resources Research 46:W10522.

Peltier, A. 2005. La gestion des risques naturels dans les montagnes d'Europe occidentale. Etude comparative du Valais (Suisse), de la Vallée d'Aoste (Italie) et des Hautes-Pyrénées (France). Accessed via https://tel.archives-ouvertes.fr/tel-00078352. 
Pfister, C. 2002. Le jour d'après: surmonter les catastrophes naturelles: le cas de la Suisse entre 1500 et 2000. Haupt, Bern/Stuttgart/Wien.

Reichen, Q. 2013. Tourismus. In: Historisches Lexikon der Schweiz (HLS), version 2013-07-17 (https://hls-dhsdss.ch/de/articles/015795/2008-11-25), visited 2020-10-01.

Reynard, E., C. Mauch, and A. Thorens. 2001. Développement historique des régimes institutionnels de l'eau en Suisse entre 1870 et 2000. In Kissling, Knoepfel, Varone: Régimes institutionnels de ressources naturelles: analyse comparée du sol, de l'eau et de la forêt. Helbing und Lichtenhahn, Basel/Frankfurt.

Roy, S.G., P.O. Koons, P. Upton, and G.E. Tucker. 2015. The influence of crustal strength fields on the patterns and rates of fluvial incision. Journal of Geophysical Research: Earth Surface 120:275-299.

Scheidl C, Heiser M, Kamper S, Thaler T, Klebinder K, Nagl F, Lechner V, Markart G, Rammer W, Seidl R. 2020. The influence of climate change and canopy disturbances on landslide susceptibility in headwater catchments. Science of the Total Environment 742:140588.

Scherrer, S.C., E.M. Fischer, R. Posselt, M.A. Liniger, M. Croci-Maspoli, and R. Knutti. 2016. Emerging trends in heavy precipitation and hot temperature extremes in Switzerland. Journal of Geophysical Research: Atmospheres 121:2626- 2637.

Schuler, A. 2007. Lois sur les forêts. Accessed via https://hls-dhs-dss.ch/articles/013802/2007-08-17/.

Schwarz, M., D. Cohen, and D. Or. 2012. Spatial characterization of root reinforcement at stand scale: theory and case study. Geomorphology 171-172:190-200.

SCR. 1880. State Council Report (Rapport du Conseil d’État), p. 65. Médiathèque Valais de Sion.

SCR. 1881. State Council Report (Rapport du Conseil d’État), p. 55. Médiathèque Valais de Sion.

SCR. 1883. State Council Report (Rapport du Conseil d’État), p. 76. Médiathèque Valais de Sion.

Seebald, J., C. Senf, M. Heiser, C. Scheidl, D. Pflugmacher, and R. Seidl. 2019. The effects of forest cover and disturbance on torrential hazards: Large-scale evidence from the Eastern Alps. Environmental Research Letters 14:114032.

SFOE. 2020. Swiss Federal Office of Energy

(https://web.archive.org/web/20180813065300/http://www.bfe.admin.ch/themen/00490/00491/index.html? lang=en), visited 2020-10-01.

Speich, M.J.R., M. Zappa, M. Scherstjanoi, and H. Lischke. 2020. FORests and HYdrology under climate change in Switzerland v1.0: a spatially distributed model combining hydrology and forest dynamics. Geoscientific Model Development 13:537-564. DOI:10.5194/gmd-13-537-2020.

Storck, P., L. Bowling, P. Wetherbee, and D. Lettenmaier. 1998. Application of a GIS-based distributed hydrology model for prediction of forest harvest effects on peak stream flow in the Pacific Northwest. Hydrological 
Processes 12:889-904.

Stuber, M., and M. Bürgi. 2001. Agrarische Waldnutzungen in der Schweiz 1800-1950. Waldweide, Waldheu, Nadel- und Laubfutter. Schweizerische Zeitschrift für Forstwesen 152:490-508.

Summermatter, S. 2005. Die Überschwemmungen von 1868 in der Schweiz: unmittelbare Reaktion und längerfristige Prävention mit näherer Betrachtung des Kantons Wallis. Traugott Bautz.

Verbunt, M., M.G. Zwaaftink, and J. Gurtz, J. 2005. The hydrologic impact of land cover changes and hydropower stations in the Alpine Rhine basin. Ecological Modelling 187:71-84.

Vereecken, H., A. Schnepf, J.W. Hopmans, M. Javaux, D. Or, T. Roose, J. Vanderborght, M.H. Young, W. Amelung, M. Aitkenhead, S.D Allison, S Assouline, et al. 2016. Modeling soil processes: review, key challenges, and new perspectives. Vadose Zone Journal 15:vzj2015.09.0131.

Viglione, A., B. Merz, N. Viet Dung, J. Parajka, T. Nester, and G. Blöschl. 2016. Attribution of regional flood changes based on scaling fingerprints, Water Resources Research 52:5322-5340.

Wahren, A., K. Schwärzel, and K.-H. Feger. 2012. Potentials and limitations of natural flood retention by forested land in headwater catchments: evidence from experimental and model studies. Journal of Flood Risk Management 5:321-335.

Wasson, R.J., N. Juyal, M. Jaiswal, M. McCulloch, M.M. Sarin, V. Jain, P. Srivastava, and A.K. Singhvi, 2008. The mountain-lowland debate: Deforestation and sediment transport in the upper Ganga catchment. Journal of Environmental Management 88:53-61.

Weiss, G. 2001. Mountain forest policy in Austria: a historical policy analysis on regulating a natural resource. Environment and History 335-355.

Woolsey, S., C. Weber, T. Gonser, E. Hoehn, M. Hostmann, B. Junker, C. Roulier, S. Schweizer, S. Tiegs, K. Tockner and A. Peter. 2005. Handbuch für die Erfolgskontrolle bei Fliessgewässerrevitalisierungen. Publikation des Rhone-Thur Projektes. Eawag, WSL, LCH-EPFL, VAW-ETHZ.

Zeh Weissmann, H., C. Könitzer, and A. Bertiller. 2009. Strukturen der Fliessgewässer in der Schweiz. Zustand von Sohle, Ufer und Umland (Ökomorphologie); Ergebnisse der ökomorphologischen Kartierung. Stand: April 2009. Umwelt-Zustand Nr. 0926. Bundesamt für Umwelt, Bern.

\section{Supplemental Material}

\section{Data origin/copy right for images and information displayed in Figure 2.}

- Base layers (e.g. river network, hillshade) and hydrometric and meteorological station and hydropower installation information were obtained from Swisstopo.

- Reforestation projects were digitized from data found in the Sion Archives. 
- Reforestation map 1934 - Swiss Federal Archives Bern, AFS EDI, E3270A\#196730\#2529, Projekt 212: Ecottis-Bataille, Gemeinde Vouvry 1933-1960.

- Historical flow record 1957 - Swiss Federal Archives Bern, AFS EDI, E8170D\#2015238\#2041: ElectroVouvry 1958.

- Current flow 2011 - Lucien Bidaud, RapportsStucky, Document № 5330 / 4002.

- Landscape images - Collections Audiovisuelles du Valais and Sion Archives, CH AEV, 69001 vol. 110, Vouvry, Troistorrents, Val d'llliez.

- Aerial images - Licensed from Swisstopo, 1942 - 19420460240848, 1969 - 19699990120657, 2004 20047010334193

\section{Figures}




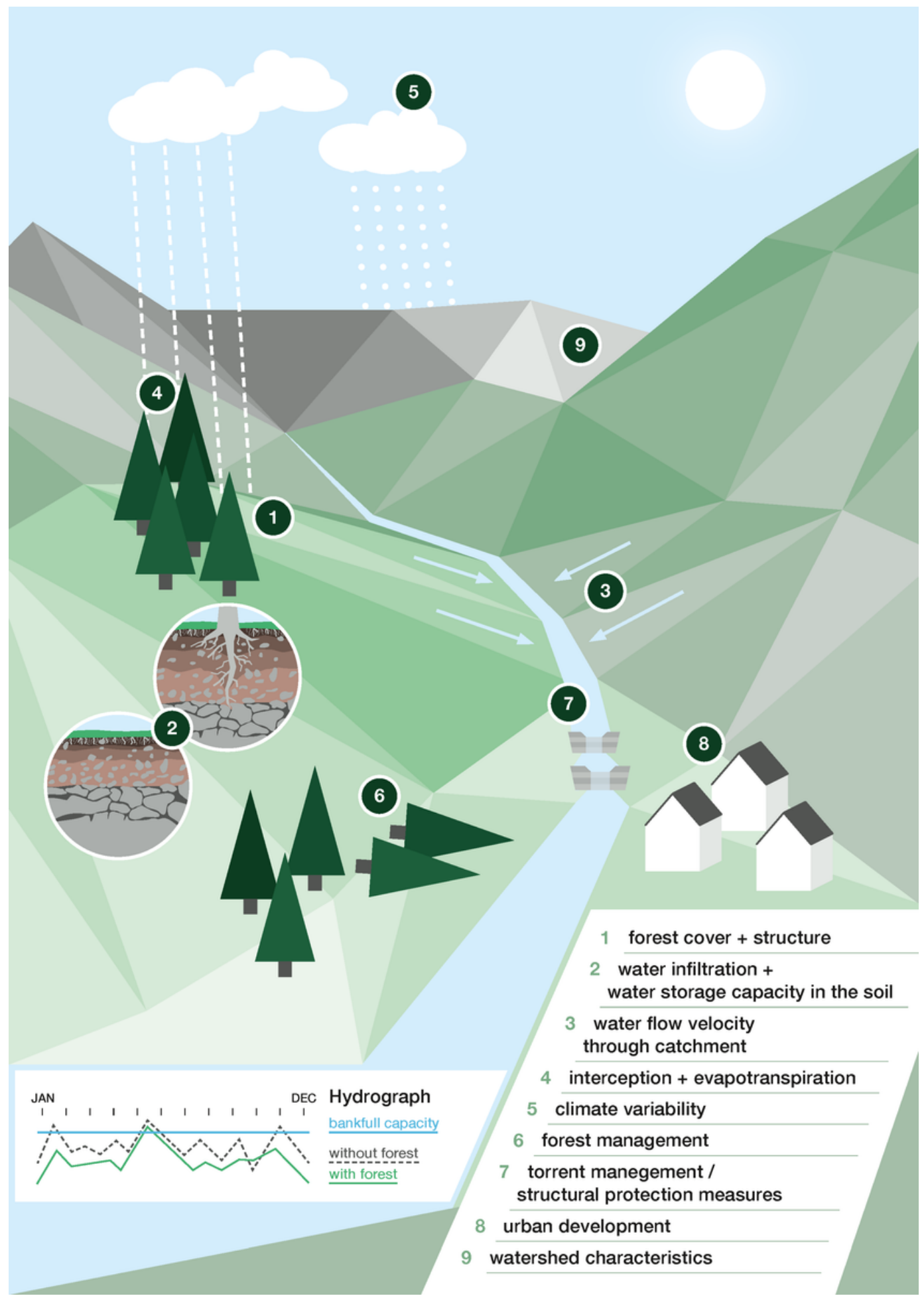

Figure 1

Conceptual representation of the different factors influencing catchment-scale runoff and how that might affect catchment hydrology. The focus is on effects of forests on catchment hydrology. 


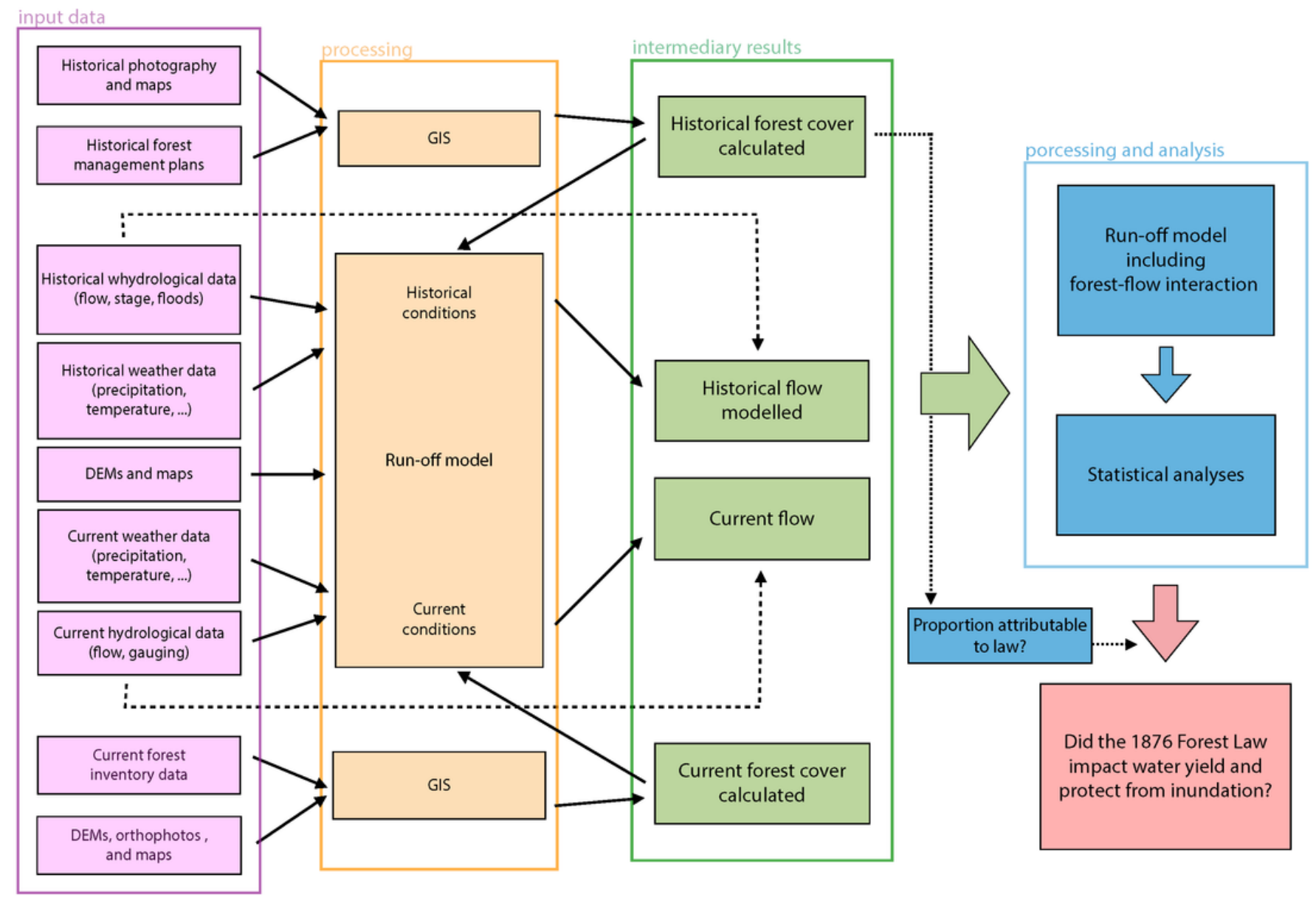

Figure 2

Proposed methodological approach to answer the research question regarding the effectiveness of flood protection via the protection of mountain forests. 


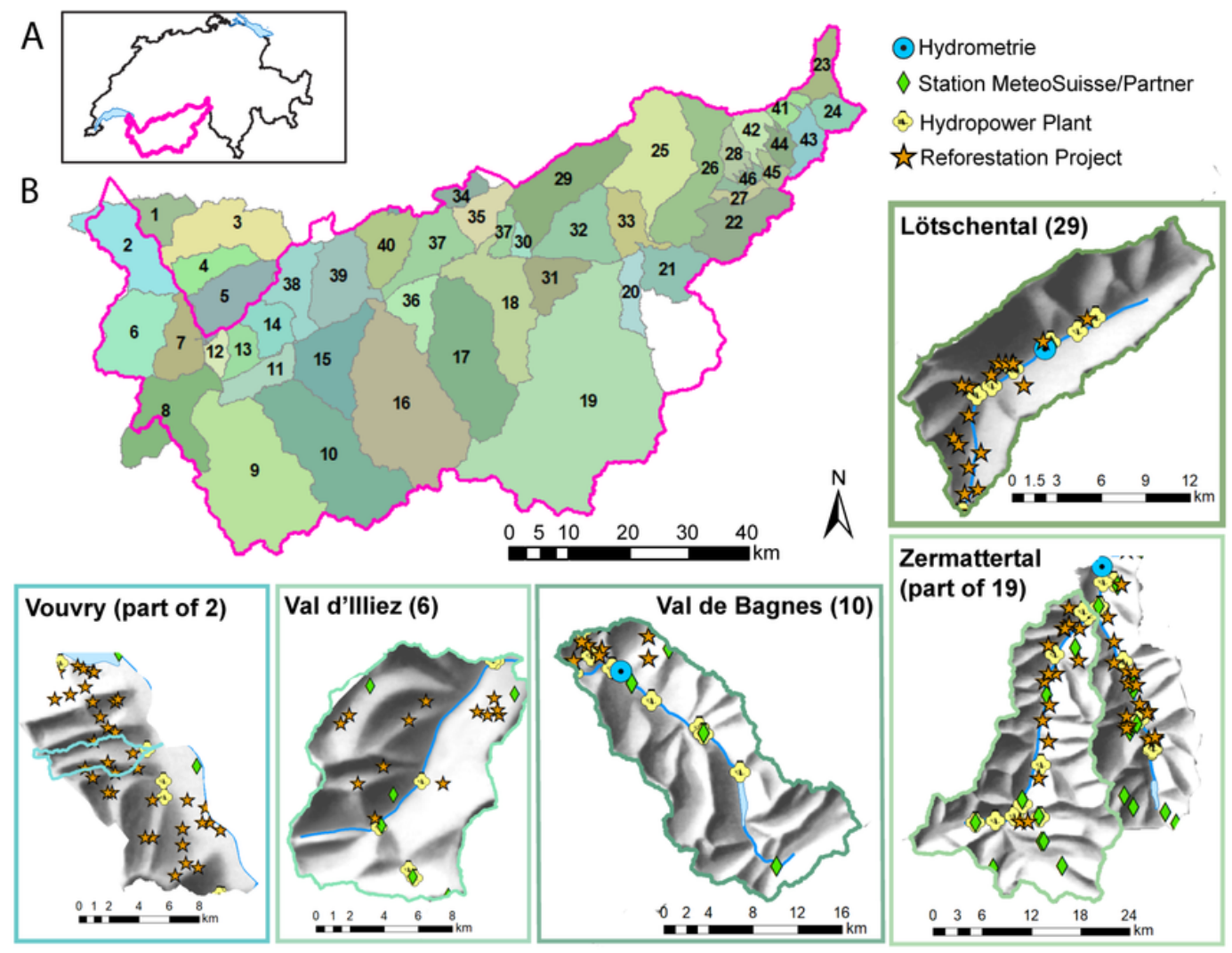

C Vouvry (excerpt data types) Historical reforestation records (1934)
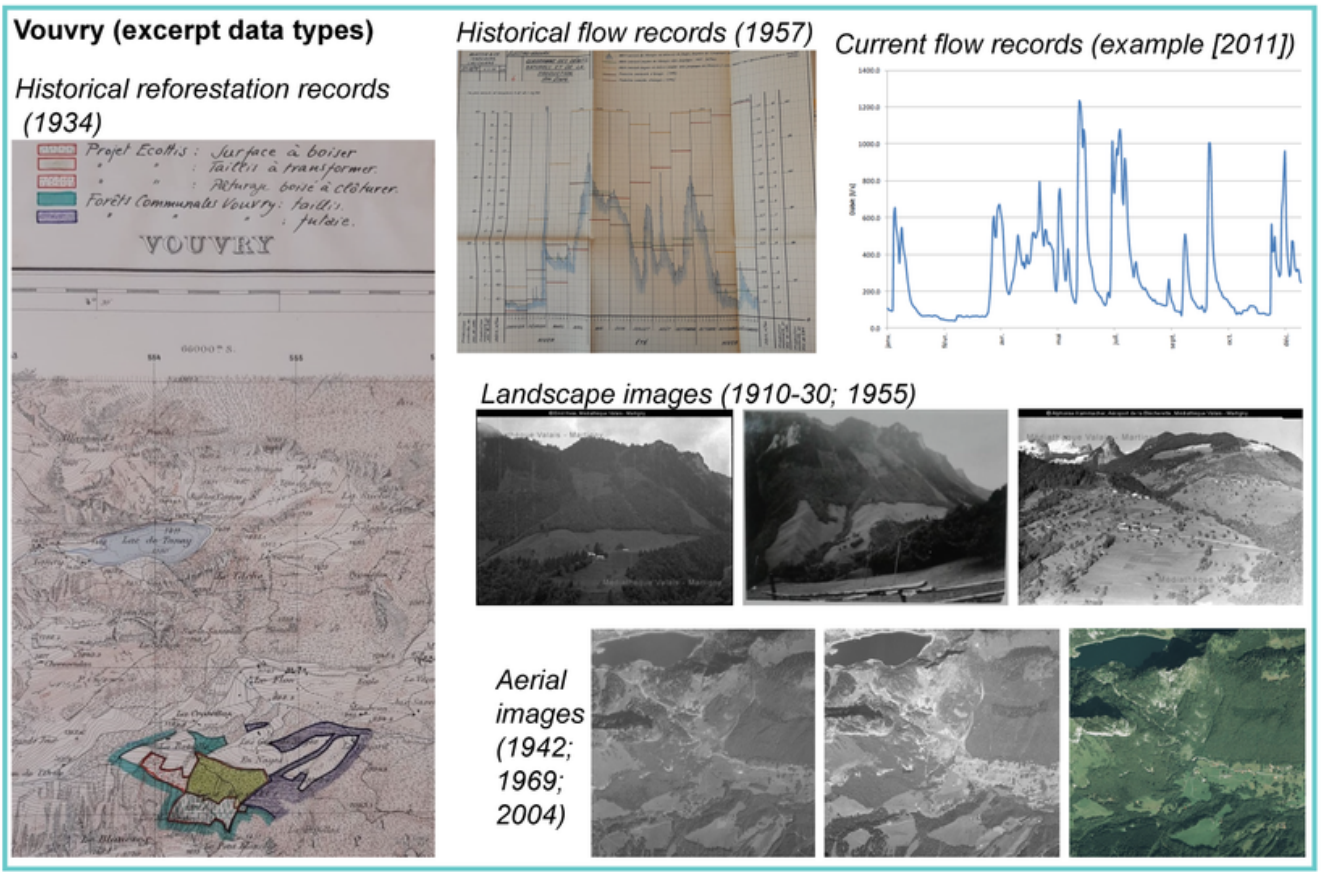

\section{Figure 3}

Data types and availability of the case study conducted in the Upper Rhone catchment. A shows the canton Valais in relation to Switzerland. B shows the delineated regions, with specific details on the five regions selected for further study. $\mathrm{C}$ shows examples of data types available. For data sources please see the Supplemental material. 